\title{
Studi Numerik Performa Rangka Bresing Konsentris Tiga Segmen dengan Sambungan Pin
}

\author{
Rizal Nur Syamsu ${ }^{1}$,, Budi Suswanto ${ }^{1}$, Harun Al Rasyid ${ }^{1}$ \\ Departemen Teknik Sipil, Institut Teknologi Sepuluh Nopember, Surabaya ${ }^{1}$ \\ Koresponden*,Email: rizalsyams33@gmail.com
}

\begin{tabular}{|c|c|c|}
\hline & Info Artikel & Abstract \\
\hline Diajukan & 02 Maret 2021 & Special Concentrically Braced Frames (SCBF) is a type of CBF which can withstand large \\
\hline Diperbaiki & 22 Maret 2021 & seismic forces and is better than Ordinary Concentrically Braced Frames (OCBF) which can \\
\hline $\begin{array}{l}\text { Keyword: } \\
\text { Rectangula } \\
\text { Connection }\end{array}$ & $\begin{array}{l}\text { entrically Braced Frames, } \\
\text { llow Structural Section, Pin }\end{array}$ & $\begin{array}{l}\text { only withstand low seismic forces. This structure will experience damage to the bracing because } \\
\text { the seismic force of the structure cannot resist buckling. The permitted SCBF configurations } \\
\text { are V, inverted V (Chevron) and X. Bracing } 3 \text { (three) segments using circular Hollow } \\
\text { Structural Section (HSS) profiles can increase inelastic strength during an earthquake. Hollow } \\
\text { structural steel (HSS) braces use a plate connection (gusset plate) that connects the beams and } \\
\text { columns. Pin joints can also be used in concentric bracing structures. The results showed that } \\
\text { a three-segment bracing structure using high quality and a slightly longer hollow end resulted } \\
\text { in high energy dissipation and longer deformation. }\end{array}$ \\
\hline
\end{tabular}

\begin{abstract}
Abstrak
Special Concentrically Braced Frames (SCBF) merupakan salah satu tipe CBF yang mana dapat menahan gaya seismik yang besar dan lebih baik daripada Ordinary Concentrically Braced Frames (OCBF) yang hanya dapat menahan gaya seismik yang rendah. Struktur ini akan mengalami kerusakan pada bresing karena gaya seismik struktur tidak bisa menahan tekuk. Konfigurasi SCBF yang diizinkan adalah V, V terbalik (Chevron) dan X. Bresing 3 (tiga) segmen menggunakan profil circular Hollow Structural Section (HSS) dapat meningkatkan kekuatan inelastic selama gempa terjadi. Bresing Hollow structural steel (HSS) menggunakan sambungan pelat (gusset plate) yang menghubungkan dengan balok dan kolom. Sambungan pin juga dapat digunakan pada struktur bresing konsentris. Hasil penelitian diperoleh struktur bresing tiga segmen dengan menggunakan mutu yang tinggi dan end hollow yang sedikit lebih panjang menghasilkan energi disipasi yang tinggi dan deformasi yang terjadi lebih panjang.
\end{abstract}

Kata kunci: Rangka Bresing Konsentris,
Rectangular Hollow Structural Section, Sambungan Pin

\section{Pendahuluan}

Concentrically Braced Frames (CBF) merupakan struktur kuat yang cocok untuk penahan angin dan beban seismik. Umumnya CBF terdiri dari bagian bresing diagonal yang tersambung ke balok dan kolom dengan menggunakan sambungan pelat gusset [1]. CBF menawarkan ekonomis dan bentuk yang efisien penahan seismik lateral untuk struktur [2]. CBF terbagi menjadi 2 berdasarkan daerah seismik yang mana Ordinary Concentrically Braced Frames (OCBF) dapat digunakan pada daerah rawan gempa rendah sedangkan Special Concentrically Braced Frames (SCBF) yang dapat digunakan pada daerah rawan gempa tinggi [3]. SCBF telah menjadi salah satu sistem penahan beban lateral yang menarik untuk peneliti setelah kurangnya kemampuan dari Special Moment Resting Frames (SMRF) saat terjadinya gempa pada tahun 1994. SCBF terdiri dari bresing, balok dan kolom serta biasanya sambungan terdapat di tengah bentang tanpa eksentrisitas.

Kekakuan elastisitas SCBF jauh lebih tinggi daripada sistem lateral baja lainnya dengan sebagian besar pengaku lateral dan disediakan melalui bresing untuk menahan respon aksial [4]. SCBF digunakan di daerah seismik tinggi dikarenakan struktur yang efisien dan khususnya daktilitas yang tinggi untuk disipasi energi melalui leleh tarik, tekuk dan perilaku bresing setelah tekuk [5]. Daktailitas bresing tercapai melalui persayatan lebar tipis yang memastikan bresing memiliki tahanan tekuk lokal yang cukup dan umur kelelahan siklik rendah untuk menahan beberapa siklik tekuk global serta leleh tarik pada deformasi aksial besar sebelum bresing mengalami fraktur [6]. SCBF dimaksudkan mempertahankan resistensi pada deformasi inelastik melalui leleh dan kegagalan yang spesifik, termasuk tekuk bresing saat tekan dan leleh tarik [7].

Ada beberapa sambungan yang biasa digunakan untuk bresing SCBF menghubungkan balok dan kolom, antara lain sambungan baut, sambungan pelat (gusset plate), dan sambungan pin. Sambungan pin saat terkena buckling inelastic, akan mengalami sendi plastic pada tengah bentang yang ditunjukkan seperti perilaku bresing [8]. Geometri sambungan pada Gambar 1 memperlihatkan sambungan yang umum digunakan dengan disambungkan pada balok-balok, balokkolom, dan terdapat geometri sambungan jepit-jepit yang 
hampir sama dengan gusset plate pada umumnya tetapi terdapat pengaku.
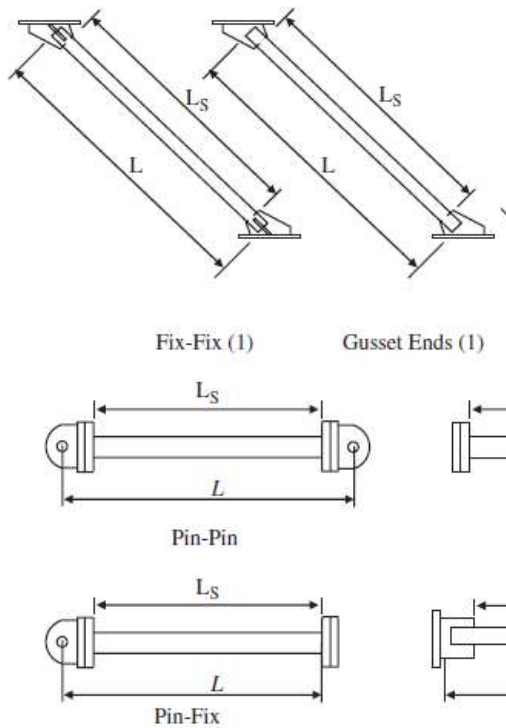

Gambar 1. Geometri sambungan yang berupa pin-pin, jepitjepit, pin-jepit dan gusset plate [8]

Penyelidikan eksperimen perilaku bresing dalam beban siklik dimulai tahun 1970 dan sejak itu Hollow Structural Section (HSS) banyak digunakan. Potongan melintang HSS sepenuhnya terlibat pada sambungan menyalurkan beban secara langsung dan menghindari kegagalan pada sambungan [9]. Profil HSS memiliki beberapa macam yaitu Circular Hollow Section (CHS), Square Hollow Section (SHS), dan Rectangular Hollow Section (RHS). Rectangular hollow section (RHS) biasanya digunakan pada desain bresing karena kemudahan menyambungkan ke rangka eksisting yang ada dan tingginya radius girasi dibandingkan bentuk penampang lainnya seperti WF dan penampang double tee [8]. Profil RHS sangant efektif dalam tekanan dan penggunaan konfigurasi X-bracing yang efisien yang menahan gaya seismik lateral dan memenuhi batas maksimal peraturan dalam ratio kelangsingan bresing [10]. Dengan menggunakan bresing HSS tabung, kegagalan daktilitas ultimate dicapai oleh inisiasi retak dan fraktur ultimate pada tengah bentang bresing tertekuk seteleh penempatan deformasi inelastik [11].

Dalam penelitian bertujuan untuk mengembangkan bresing baja dengan menggunakan bentuk struktur konvensional yang meningkatkan kapasitas deformasi inelastik yang signifikan terutama melalui lelehnya pada tegangan maupun dari tekanan [12].

\section{Metode}

Dalam pemodelan dan analisa numerik dilakukan bertujuan untuk mengetahui perilaku bresing konsentris saat menerima beban siklik saat dilakukan pengujian. Empat spesimen bresing yang dimodelkan dengan menggunakan program Abaqus. Spesimen yang diteliti mengikuti refrensi dari penelitian Seker dkk [13] dengan memodelkan bresing konsentris dengan 3 bagian hollow. Dalam penelitian tersebut menggunakan 3 hollow dengan tiap hollow disambung dengan sambungan las serta ujung bresing menggunakan sambungan gusset plate.

Permodelan analisa numerik terhadap spesimen yaitu SP1, SP2, SP3 dan SP4 menggunakan program Abaqus. Semua spesimen dimodelkan sesuai dengan Gambar 2 hingga Gambar 3. Semua spesimen menggunakan ukuran profil yang sama dan yang membedakan setiap spesimen adalah mutu yang digunakan dan panjang profil. Spesimen SP1 diilustrasikan pada Gambar 2 dengan menggunakan mutu baja BJ41 dengan $f y=250 \mathrm{MPa}$ dan $f u=410 \mathrm{MPa}$ pada semua segmen yang digunakan.

Seperti pada Gambar 2 imerupakan spesimen SP2 yang mana ukuran profil, panjang profil tidak beda pada spesimen SP1. Yang membedakan SP1 dan SP2 adalah mutu baja yang digunakan selain center hollow menggunakan BJ 37 dengan $f y=240 \mathrm{MPa}$ dan $f u=370 \mathrm{MPa}$. Center hollow menggunakan mutu BJ 41. Tujuan membedakan mutu pada end hollow dengan center hollow adalah memperlihatkan seberapa jauh perbedaan saat terjadi leleh atau tekuk pada end hollow. Pada spesimen SP3 memilik perbedaan pada panjanng end hollow dengan menggunakan mutu BJ 41. Panjang end hollow spesimen SP3 lebih pendek daripada spesimen spesimen sebelumnya seperti pada Gambar 3. Sedangkan spesimen SP4 memiliki kesamaan dengan spesimen SP3 pada panjang end hollow seperti pada Gambar 3. Pembedan dari spesimen SP3 dan SP4 adalah mutu yang digunakan selain center hollow adalah mutu BJ 37. Untuk lebih lengkap ukurang profil yang digunakan dapat dilihat pada Tabel 1.

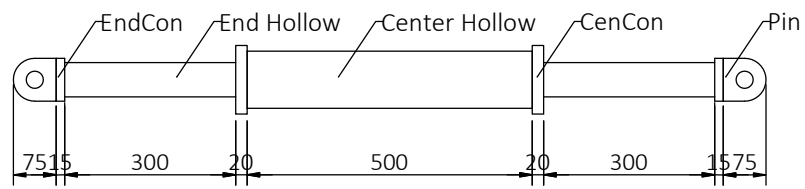

Gambar 2. Spesimen SP1 dan SP2

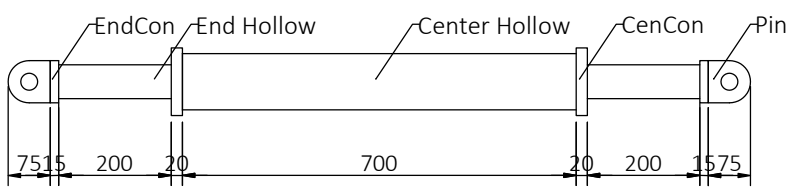

Gambar 3. Spesimen SP3 dan SP4 
Tabel 1. Profil Rangka Bresing Konsentris

\begin{tabular}{|c|c|c|c|c|}
\hline No & Nama Spesimen & Segmen & Dimensi & Material \\
\hline \multirow{5}{*}{1} & \multirow{5}{*}{ SP1 } & Center Hollow & $100 \times 100 \times 4,5$ & BJ 41 \\
\hline & & Center Connection & $120 \times 120 \times 20$ & BJ 41 \\
\hline & & End Hollow & $60 \times 60 \times 4$ & BJ 41 \\
\hline & & End Connection & $75 \times 75 \times 15$ & BJ 41 \\
\hline & & Pin & $75 \times 75 \times 15$ & BJ 41 \\
\hline \multirow{5}{*}{2} & \multirow{5}{*}{$\mathrm{SP} 2$} & Center Hollow & $100 \times 100 \times 4,5$ & BJ 41 \\
\hline & & Center Connection & $120 \times 120 \times 20$ & BJ 37 \\
\hline & & End Hollow & $60 \times 60 \times 4$ & BJ 37 \\
\hline & & End Connection & $75 \times 75 \times 15$ & BJ 37 \\
\hline & & Pin & $75 \times 75 \times 15$ & BJ 37 \\
\hline \multirow{5}{*}{3} & \multirow{5}{*}{ SP3 } & Center Hollow & $100 \times 100 \times 4,5$ & BJ 41 \\
\hline & & Center Connection & $120 \times 120 \times 20$ & BJ 41 \\
\hline & & End Hollow & $60 \times 60 \times 4$ & BJ 41 \\
\hline & & End Connection & $75 \times 75 \times 15$ & BJ 41 \\
\hline & & Pin & $75 \times 75 \times 15$ & BJ 41 \\
\hline \multirow{5}{*}{4} & \multirow{5}{*}{ SP4 } & Center Hollow & $100 \times 100 \times 4,5$ & BJ 41 \\
\hline & & Center Connection & $120 \times 120 \times 20$ & BJ 37 \\
\hline & & End Hollow & $60 \times 60 \times 4$ & BJ 37 \\
\hline & & End Connection & $75 \times 75 \times 15$ & BJ 37 \\
\hline & & Pin & $75 \times 75 \times 15$ & BJ 37 \\
\hline
\end{tabular}

Pemodelan spesimen menggunakan program bantu analisa Abaqus. Pemodelan spesimen pada Abaqus sesuai dengan Gambar 2 dan Gambar 3. Awal pemodelan menggunakan base feature dengan shape berupa solid. Solid element adalah elemen standar pada Abaqus yang sering digunakan. Elemen tersebut mempunyai 8 nodal yang mana tiap nodal memiliki tiga degree of freedom (DOF) antara lain $u_{1}, u_{2}$, dan $u_{3}$. Tiap elemen pada spesimen yang akan diteliti menggunakan model C3D8R dengan ukuran meshing sebesar $20 \mathrm{~mm}$. Penggunaaan reduce integration elements pada spesimen bermaksud untuk meningkatkan analisa pada pemodelan tanpa mengurangi hasil akurasinya.

Mutu material pada spesimen merupakan mutu yang sesuai dengan SNI 03-1729-2002 [14] seperti pada Tabel 2. Spesifikasi meterial diperlukan saat pemodelan Abaqus yang merupakan elemen penting dalam pemodelan karena memberikan pengaruh pada hasil akhir. Material spesimen menggunakan aturan kinematic hardening untuk material nonlinier.
Tabel 2. Spesifikasi Material Bresing [14]

\begin{tabular}{llll}
\hline Jenis Mutu & $\begin{array}{l}\text { Tegangan } \\
\text { putus } \\
\text { minimum } \\
(f u)\end{array}$ & $\begin{array}{l}\text { Tegangan } \\
\text { leleh } \\
\text { minimum } \\
(f y)\end{array}$ & $\begin{array}{l}\text { Peregangan } \\
\text { minimum } \\
(\%)\end{array}$ \\
\hline BJ37 & 370 & 240 & 20 \\
BJ41 & 410 & 250 & 18 \\
Modulus Young $(\mathrm{E})$ & $: 200.000 \mathrm{MPa}$ \\
Modulus Geser $(\mathrm{G})$ & $: 80.000 \mathrm{MPa}$ \\
Poisson Ratio $(\mu)$ & $: 0,3$ \\
Berat Jenis & $: 7.850 \mathrm{~kg} / \mathrm{m}^{3}$ \\
\hline
\end{tabular}

Pembebanan pada spesimen diinput ke boundary condition. Pembebanan siklik pada ujung spesimen menggunakan displacement bernilai -1 terhadap $u_{3}$ yang berupa amplitude yang sesuai dengan Gambar 4. Pembebanan ini sama dilakukan oleh penelitian Seker dkk sebelumnya akan tetapi satuan displacement diubah menggunakan satuan SI. 


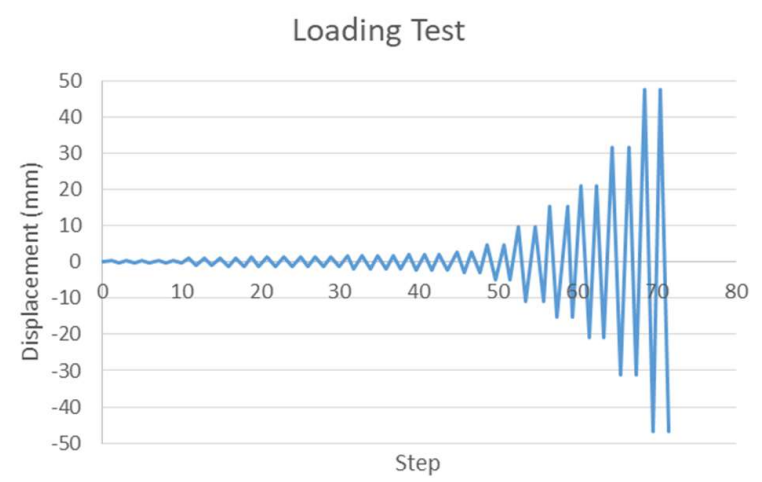

Gambar 4. Loading protocol [12]

Perletakan pemodelan spesimen menggunakan sendi sendi sebab pemodelan menggunakan sambungan pin-pin pada ujung spesimen. Saat pemodelan berlangsung, beban displacement secara bertahap meningkat (incremental) pada ujung salah satu sendi seperti pada Gambar 5.

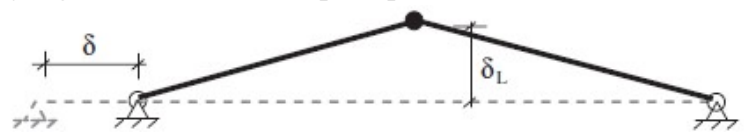

Gambar 5. Skema pembebanan displacement dengan perletakan sendi sendi [8]

Untuk interaksi pada tiap part menggunakan interaction dengan tipe tie constraint. Penggunaan tie constraint dianggap tiap part telah menyatu sepenuhnya selayaknya menggunakan sambungan las.

\section{Hasil dan Pembahasan}

\section{A. Spesimen SP1}

Pada spesimen SP1 memodelkan bresing menggunakan mutu BJ 41 pada semua element. Pada center hollow sepanjang 500mm sedangkan untuk end hollow sepanjang 300mm. Spesimen SP1 mencapai tegangan leleh $250 \mathrm{MPa}$ diperoleh displacement sebesar 1,149 mm yang menandakan bresing sudah mengalami leleh pertama. Gambar 6 menunjukkan bresing pada saat mencapai tegangan puncak $410 \mathrm{MPa}$ mengalami displacement sebesar 24,06 mm.

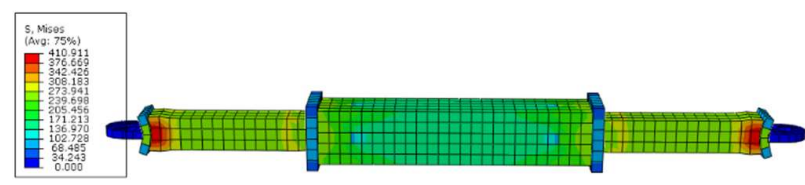

Gambar 6. Spesimen SP1 saat mengalami leleh awal

Kurva histeresis merupakan hasil analisa Abaqus dengan membandingkan gaya tekan dan rotasi yang terjadi pada bresing. Gaya tekan (reaction force) diperoleh dari hasil analisa, sedangkan rotasi merupakan hasil konversi dari displacement yang mana dibagi dengan panjang bresing. Gambar 7 merupakan kurva histeresis hasil analisa spesimen SP1 yang diperoleh setelah pemodelan pada Abaqus.

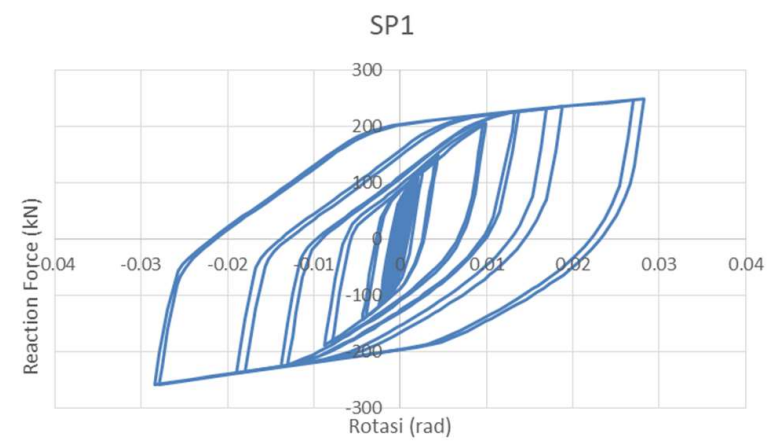

Gambar 7. Kurva histerisis spesimen SP1

Pada kurva histeresis diperoleh selama pembebanan siklik yang dimodelkan pada analisa Abaqus. Pada kurva di atas, diperoleh tegangan maksimum dengan reaction force 244,156 kN saat rotasi mencapai 0,0021 rad. Pada saat leleh pertama rotasi yang dicapai ialah $0,001 \mathrm{rad}$ dengan reaction force $88,65 \mathrm{kN}$. Pada spesimen SP1 diperoleh energi disipasi sebesar 24,14 kNm. Dari perolehan analisa Abaqus, pada kondisi leleh pertama dan saat keadaan ultimate dapat dilihat pada Tabel 3. Leleh awal terjadi saat siklus ke 55 pada ujung end hollow sedangkan saat terjadi ultimate mencapai pada siklus ke 697. Dari analisa gaya maksimal mencapai 266,774 $\mathrm{kN}$ saat siklus ke 838 dengan displacement 46,979 mm.

Tabel 3. Kondisi saat spesimen SP1 mengalami leleh pertama dan ultimate

\begin{tabular}{lllll}
\hline & $\begin{array}{l}\text { Siklus } \\
\text { ke- }\end{array}$ & $\begin{array}{l}\text { Displacement } \\
(\mathrm{mm})\end{array}$ & $\begin{array}{l}\text { Rotasi } \\
(\mathrm{rad})\end{array}$ & $\begin{array}{l}\text { Reaction } \\
\text { Force } \\
(\mathrm{kN})\end{array}$ \\
\hline $\begin{array}{l}\text { Leleh } \\
\text { Awal }\end{array}$ & 55 & 1,149 & 0,001044 & 88,646 \\
$\begin{array}{l}\text { Ultimate } \\
\text { Gaya } \\
\text { maks }\end{array}$ & 697 & 24,066 & 0,002188 & 244,156 \\
\hline
\end{tabular}

\section{B. Spesimen SP2}

Yang membedakan spesimen SP2 dengan spesimen SP1 adalah mutu yang digunakan pada semua element selain center hollow menggunakan mutu BJ37. Tujuan menggunakan mutu BJ37 end hollow adalah agar pada elemen end hollow mengalami leleh terlebih dahulu. Spesimen SP2 mencapai tegangan leleh $240 \mathrm{MPa}$ diperoleh displacement sebesar 0,86987 mm yang menandakan bresing sudah mengalami leleh pertama. Sedangkan Gambar 8 bresing telah mencapai tegangan puncak $370 \mathrm{MPa}$ mengalami displacement sebesar $23,68 \mathrm{~mm}$. 


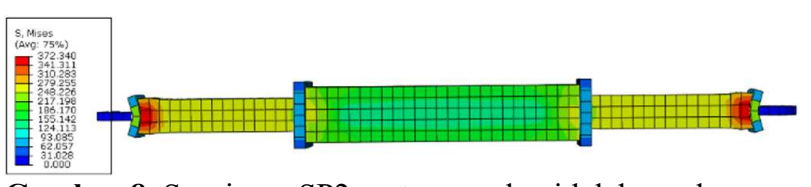

Gambar 8. Spesimen SP2 saat mengalami leleh awal

Pada kurva histeresis diperoleh selama pembebanan siklik yang dimodelkan pada analisa abaqus. Kurva histeresis pada Gambar 9, diperoleh tegangan maksimum dengan reaction force $231,4 \mathrm{kN}$ saat rotasi mencapai $0,0215 \mathrm{rad}$. Pada saat leleh pertama rotasi yang dicapai ialah 0,00079 rad dengan reaction force $73,8 \mathrm{kN}$. Pada spesimen SP2 diperoleh energi disipasi sebesar 23,614 kNm.

Dari perolehan analisa Abaqus, pada kondisi leleh pertama dan saat keadaan ultimate dapat dilihat pada Tabel 4. Leleh awal terjadi saat siklus ke 39 pada ujung end hollow sedangkan saat terjadi ultimate mencapai pada siklus ke 707. Dari analisa gaya maksimal mencapai $266,71 \mathrm{kN}$ saat siklus ke 837 dengan displacement 44,038mm.

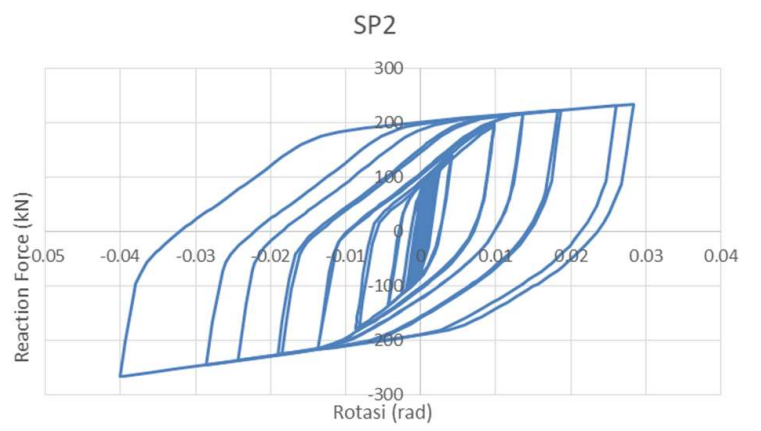

Gambar 9. Kurva histerisis spesimen SP2

Tabel 4. Kondisi saat spesimen SP2 mengalami leleh pertama dan ultimate

\begin{tabular}{lllll}
\hline & $\begin{array}{l}\text { Siklus } \\
\text { ke- }\end{array}$ & $\begin{array}{l}\text { Displacement } \\
(\mathrm{mm})\end{array}$ & $\begin{array}{l}\text { Rotasi } \\
(\mathrm{rad})\end{array}$ & $\begin{array}{l}\text { Reaction } \\
\text { Force } \\
(\mathrm{kN})\end{array}$ \\
\hline $\begin{array}{l}\text { Leleh } \\
\text { Awal }\end{array}$ & 39 & 0,8696 & 0,00079 & 73,804 \\
$\begin{array}{l}\text { Ultimate } \\
\text { Gaya } \\
\text { maks }\end{array}$ & 707 & 23,681 & 0,021527 & 231,413 \\
\hline
\end{tabular}

\section{Spesimen SP3}

Pada spesimen SP3 terdapat perbedaan pada panjang end hollow dengan spesimen spesimen sebelumya. End hollow menggunakan panjang profil $200 \mathrm{~mm}$ sedangkan center hollow menggunakan panjang $700 \mathrm{~mm}$. Semua element menggunakan mutu BJ41. Spesimen SP3 mencapai tegangan leleh $250 \mathrm{MPa}$ diperoleh displacement sebesar $0,8 \mathrm{~mm}$ yang menandakan bresing sudah mengalami leleh pertama. Hasil bresing pada Gambar 10 menunjukkan saat spesimen SP3 mencapai tegangan puncak $410 \mathrm{MPa}$ mengalami displacement sebesar 21,05 $\mathrm{mm}$.

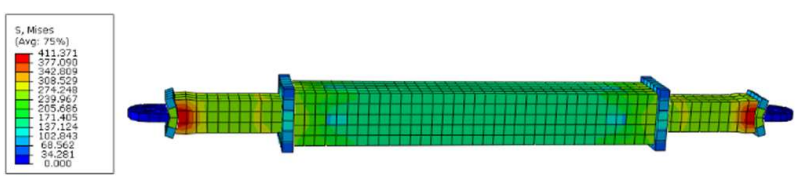

Gambar 10. Spesimen SP3 saat mengalami leleh awal

Pada kurva histeresis diperoleh selama pembebanan siklik yang dimodelkan pada analisa abaqus. Kurva histeresis pada Gambar 11, diperoleh tegangan maksimum dengan reaction force $244,913 \mathrm{kN}$ saat rotasi mencapai $0,019 \mathrm{rad}$. Pada saat leleh pertama rotasi yang dicapai ialah $0.0007 \mathrm{rad}$ dengan reaction force $69,813 \mathrm{kN}$. Pada spesimen SP3 diperoleh energi disipasi sebesar $24,129 \mathrm{kNm}$.

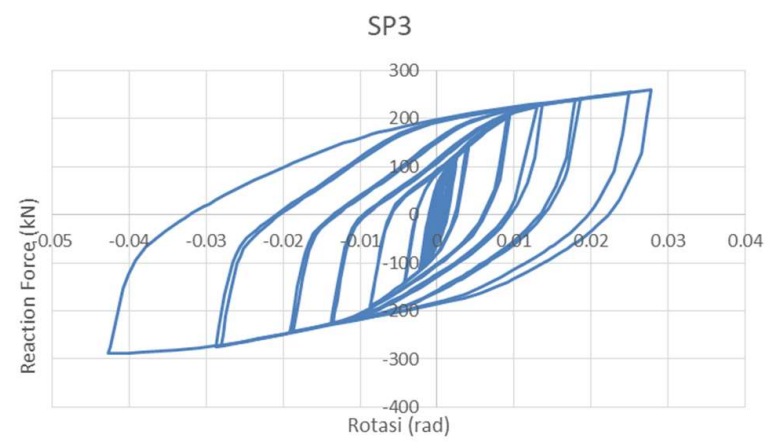

Gambar 11. Kurva histerisis spesimen SP3

Tabel 5. Kondisi saat spesimen SP3 mengalami leleh pertama dan ultimate

\begin{tabular}{lllll}
\hline & $\begin{array}{l}\text { Siklus } \\
\text { ke- }\end{array}$ & $\begin{array}{l}\text { Displacement } \\
(\mathrm{mm})\end{array}$ & $\begin{array}{l}\text { Rotasi } \\
(\mathrm{rad})\end{array}$ & $\begin{array}{l}\text { Reaction } \\
\text { Force } \\
(\mathrm{kN})\end{array}$ \\
\hline $\begin{array}{l}\text { Leleh } \\
\text { Awal }\end{array}$ & 41 & 0,8078 & 0,000734 & 69,813 \\
$\begin{array}{l}\text { Ultimate } \\
\text { Gaya } \\
\text { maks }\end{array}$ & 617 & 21,049 & 0,019135 & 244,91 \\
\hline
\end{tabular}

Dari perolehan analisa Abaqus, pada kondisi leleh pertama dan saat keadaan ultimate dapat dilihat pada Tabel 5. Leleh awal terjadi saat siklus ke 41 pada ujung end hollow sedangkan saat terjadi ultimate mencapai pada siklus ke 617. Dari analisa gaya maksimal mencapai $288,67 \mathrm{kN}$ saat siklus ke 881 dengan displacement $46,962 \mathrm{~mm}$.

\section{Spesimen SP4}

Pada spesimen SP4 ini panjang end hollow dan panjang center hollow sama dengan spesimen SP3 tetapi semua 
elemen selain center hollow menggunakan mutu BJ7 yang memiliki $f u$ sebesar $370 \mathrm{MPa}$ sedangkan $f y$ sebesar $240 \mathrm{MPa}$. Spesimen SP4 mencapai tegangan leleh $240 \mathrm{MPa}$ diperoleh displacement sebesar $0,8 \mathrm{~mm}$ yang menandakan bresing sudah mengalami leleh pertama. Gambar 12 menujukkan bahwa bresing pada saat mencapai tegangan puncak $370 \mathrm{MPa}$ mengalami displacement sebesar 19,5mm.

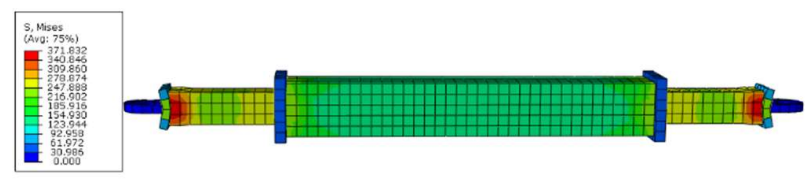

Gambar 1. Spesimen SP4 saat mengalami leleh awal

Pada kurva histeresis diperoleh selama pembebanan siklik yang dimodelkan pada analisa abaqus. Kurva histeresis pada Gambar 13, diperoleh tegangan maksimum dengan reaction force $232,7 \mathrm{kN}$ saat rotasi mencapai 0,019 rad. Pada saat leleh pertama rotasi yang dicapai ialah 0.00073rad dengan reaction force $69,51 \mathrm{kN}$. Pada spesimen SP4 diperoleh energi disipasi sebesar 22,71 kNm.

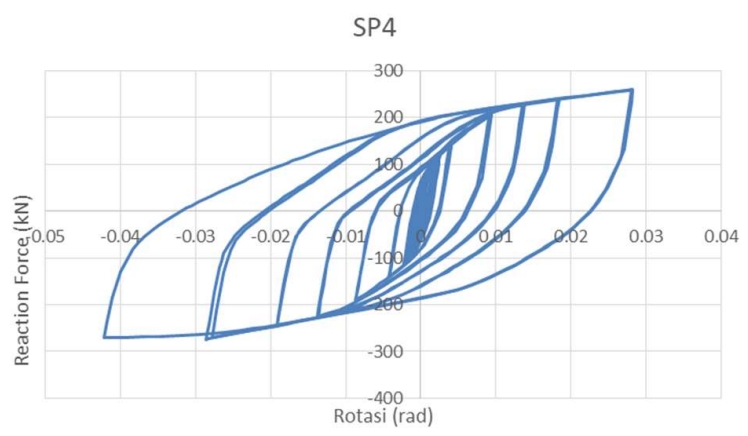

Gambar 13. Kurva histerisis spesimen SP4

Tabel 6. Kondisi saat spesimen SP4 mengalami leleh pertama dan ultimate

\begin{tabular}{lllll}
\hline & $\begin{array}{l}\text { Siklus } \\
\text { ke- }\end{array}$ & $\begin{array}{l}\text { Displacement } \\
(\mathrm{mm})\end{array}$ & $\begin{array}{l}\text { Rotasi } \\
(\mathrm{rad})\end{array}$ & $\begin{array}{l}\text { Reaction } \\
\text { Force } \\
(\mathrm{kN})\end{array}$ \\
\hline $\begin{array}{l}\text { Leleh } \\
\text { Awal }\end{array}$ & 41 & 0,8078 & 0,00073 & 69,51 \\
$\begin{array}{l}\text { Ultimate } \\
\begin{array}{l}\text { Gaya } \\
\text { maks }\end{array}\end{array}$ & 665 & 20,93 & 0,019 & 232,7 \\
\hline
\end{tabular}

Dari perolehan analisa Abaqus, pada kondisi leleh pertama dan saat keadaan ultimate dapat dilihat pada Tabel 6. Leleh awal terjadi saat siklus ke 41 pada ujung end hollow sedangkan saat terjadi ultimate mencapai pada siklus ke 665 . Dari analisa gaya maksimal mencapai $271,19 \mathrm{kN}$ saat siklus ke 877 dengan displacement 47,393mm.

\section{E. Perbandingan Antar Spesimen \\ 1) Spesimen SP1 dan Spesimen SP2}

Dari hasil analisa numerik keempat spesimen akan dibandingkan untuk mengetahui perbandingan antar spesimen yang dimodelkan. Perbandingan menggunakan kurva histeress pada tiap spesimen.

Pada Gambar 14 menunjukkan perbedaan yang tidak signifikan. Energi disipasi diperoleh dari luasan kurva histeresis. Berdasarkan luasan pada spesimen SP1 diperoleh energi disipasi 24,14 $\mathrm{kN}$ sedangkan pada spesimen SP2 diperoleh energi disipasi sebesar $23,614 \mathrm{kN}$.

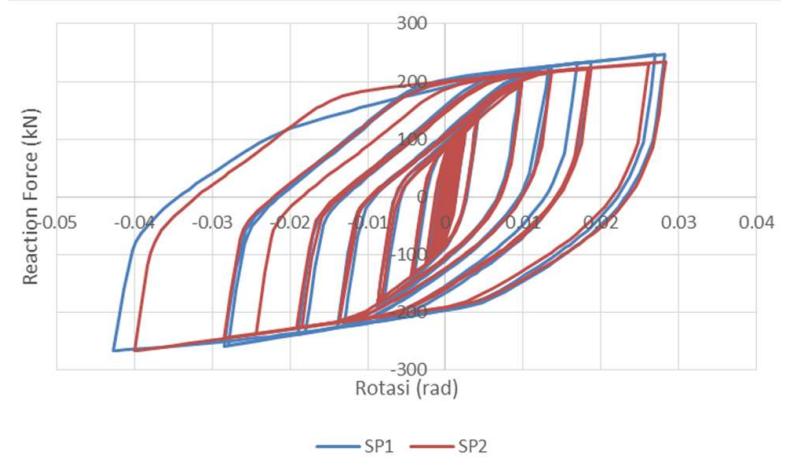

Gambar 2. Perbandingan kurva histerisis spesimen SP1 dan spesimen SP2

Dari luasan kurva histeresis spesimen, energi disipasi spesimen SP1 lebih besar dari spesimen SP2 dengan selisih $0,526 \mathrm{kNm}$ atau sebesar $2,18 \%$ yang dapat dilihat pada Tabel 7.

Tabel 7. Perbandingan Energi Disipasi Spesimen SP1 dan Spesimen SP2

\begin{tabular}{ccc} 
Spesimen & $\begin{array}{c}\text { Energi Disipasi } \\
(\mathbf{k N m})\end{array}$ & Selisih (\%) \\
\cline { 1 - 2 } SP1 & 24,14 & $2,18 \%$ \\
\hline SP2 & 23,614 & \\
\hline
\end{tabular}

Tabel 8. Perbandingan Deformasi Spesimen SP1 dan Spesi men SP2 saat Mencapai Tegangan Maksimum

\begin{tabular}{ccc} 
Spesimen & Deformasi (mm) & Selisih (\%) \\
\cline { 1 - 2 } SP1 & 24,066 & $1,60 \%$ \\
\hline SP2 & 23,68 & \\
\hline
\end{tabular}

Dari perbandingan kedua spesimen, deformasi yang terjadi saat spesimen mencapai kondisi ultimate spesimen SP1 lebih besar 0,386 $\mathrm{mm}$ daripada spesimen SP2 atau sebesar 1,6\% dapat dilihat pada Tabel 8 . 
Sedangkan perbandingan terkait reaction force terbesar seperti pada Tabel 9, bahwa spesimen SP1 sedikit lebih besar $0,064 \mathrm{kN}$ daripada spesimen SP2 atau sebesar $0,02 \%$.

Tabel 9. Perbandingan Reaction Force Maksimum Spesimen SP1 dan Spesimen SP2

\begin{tabular}{ccc} 
Spesimen & $\begin{array}{c}\text { Reaction Force } \\
\text { Maksimum (kN) }\end{array}$ & Selisih (\%) \\
\hline SP1 & 266,774 & $0,02 \%$ \\
\hline SP2 & 266,71 & \\
\hline
\end{tabular}

\section{2) Spesimen SP3 dan Spesimen SP4}

Perbandingan kurva histeresis pada Gambar 15 terdapat perbedaan yang sedikit mencolok dimana luasan kurva histeresis pada spesimen SP3 diperoleh energi disipasi $24,129 \mathrm{kN}$ lebih besar daripada spesimen SP4 diperoleh energi disipasi sebesar $22,71 \mathrm{kN}$.

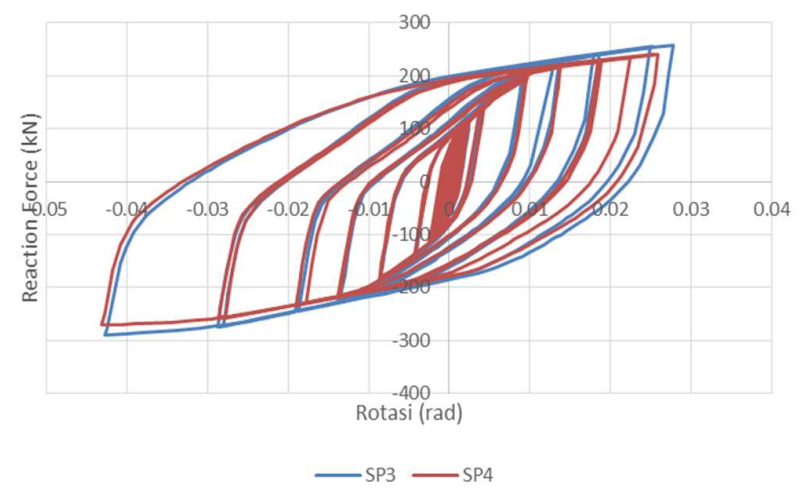

Gambar 3. Perbandingan kurva histerisis spesimen SP3 dan spesimen SP4.

Dari luasan kurva histeresis spesimen, energi disipasi spesimen SP3 lebih besar dari spesimen SP4 dengan selisih $0,1,419 \mathrm{kNm}$ atau sebesar $5,88 \%$ yang dapat dilihat pada Tabel 10.

Tabel 10. Perbandingan Energi Disipasi spesimen SP3 dan spesimen SP4

\begin{tabular}{ccc}
\hline Spesimen & $\begin{array}{c}\text { Energi Disipasi } \\
(\mathbf{k N m})\end{array}$ & Selisih (\%) \\
\cline { 1 - 2 } SP3 & 24,129 & $5,88 \%$ \\
\hline SP4 & 22,71 & \\
\hline
\end{tabular}

Dari perbandingan kedua spesimen, deformasi yang terjadi saat spesimen mencapai kondisi ultimate spesimen SP3 lebih besar $0,15 \mathrm{~mm}$ daripada spesimen SP4 atau sebesar 0,71\% dapat dilihat pada Tabel 11.
Tabel 11. Perbandingan Deformasi Spesimen SP3 dan Spesimen SP4 saat Mencapai Tegangan Maksimum

\begin{tabular}{ccc} 
Spesimen & Deformasi (mm) & Selisih (\%) \\
\cline { 1 - 2 } SP3 & 21,049 & $0,71 \%$ \\
\hline SP4 & 20,9 & \\
\hline
\end{tabular}

Sedangkan perbandingan terkait reaction force terbesar seperti pada Tabel 12, bahwa spesimen SP3 lebih besar $17,48 \mathrm{kN}$ daripada spesimen SP4 atau sebesar 6,06\%.

Tabel 12. Perbandingan Reaction Force Maksimum Spesimen SP3 dan Spesimen SP4

\begin{tabular}{ccc}
\hline Spesimen & $\begin{array}{c}\text { Reaction Force } \\
\text { Maksimum (kN) }\end{array}$ & Selisih (\%) \\
\hline SP3 & 288,67 & $6,06 \%$ \\
\hline SP4 & 271,19 & \\
\hline
\end{tabular}

\section{3) Spesimen SP1 dan Spesimen SP3}

Pada Gambar 16 menunjukkan perbedaan yang relatif sama. Berdasarkan luasan pada spesimen SP1 diperoleh energi disipasi 24,14kN sedikit lebih kecil daripada spesimen SP3 diperoleh energi disipasi sebesar 24,129kN.

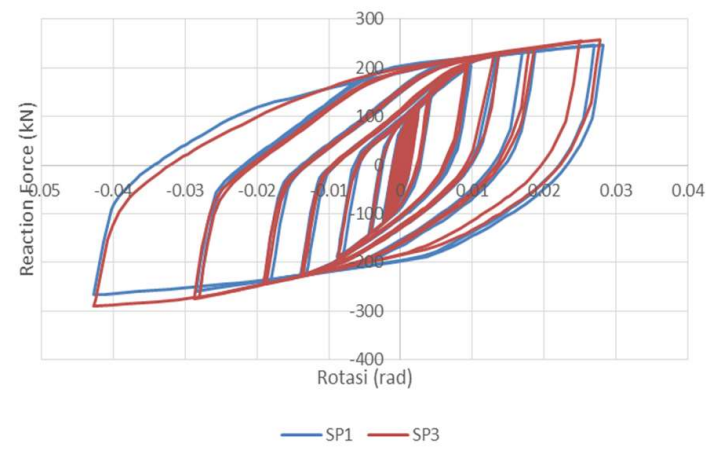

Gambar 46. Perbandingan kurva histerisis spesimen SP1 dan spesimen SP3.

Dari luasan kurva histeresis spesimen, spesimen SP1 sedikit lebih besar dari spesimen SP3 dengan selisih $0,011 \mathrm{kNm}$ atau sebesar $0,05 \%$ yang dapat dilihat pada Tabel 13.

Tabel 13. Perbandingan Energi Disipasi Spesimen SP1 dan Spesimen SP3

\begin{tabular}{ccc} 
Spesimen & $\begin{array}{c}\text { Energi Disipasi } \\
(\mathbf{k N m})\end{array}$ & Selisih (\%) \\
\cline { 1 - 2 } SP1 & 24,14 & $0,05 \%$ \\
\hline SP3 & 24,129 & \\
\hline
\end{tabular}


Dari perbandingan kedua spesimen, deformasi yang terjadi saat spesimen mencapai kondisi ultimate spesimen SP1 lebih besar $0,386 \mathrm{~mm}$ daripada spesimen SP3 atau sebesar 1,6\% dapat dilihat pada Tabel 14.

Tabel 14. Perbandingan Deformasi Spesimen SP1 dan Spesimen SP3 saat Mencapai Tegangan Maksimum

\begin{tabular}{ccc} 
Spesimen & Deformasi (mm) & Selisih (\%) \\
\hline SP1 & 24,066 & \multirow{2}{*}{$12,53 \%$} \\
\hline SP3 & 23,68 & \\
\hline
\end{tabular}

Sedangkan perbandingan terkait reaction force terbesar seperti pada Tabel 15, bahwa spesimen SP3 lebih besar 21,896 kN daripada spesimen SP1 atau sebesar 7,59\%.

Tabel 15. Perbandingan Reaction Force Maksimum Spesimen SP1 dan Spesimen SP3

\begin{tabular}{ccc}
\hline Spesimen & $\begin{array}{c}\text { Reaction Force } \\
\text { Maksimum (kN) }\end{array}$ & Selisih (\%) \\
\hline SP1 & 266,774 & $7,59 \%$ \\
\hline SP3 & 288,67 & \\
\hline
\end{tabular}

\section{4) Spesimen SP2 dan Spesimen SP4}

Pada Gambar 17 menunjukkan perbedaan yang sedikit mencolok. Berdasarkan luasan pada spesimen SP2 diperoleh energi disipasi 23,614kN sedangkan pada spesimen SP4 diperoleh energi disipasi sebesar $22,71 \mathrm{kN}$.

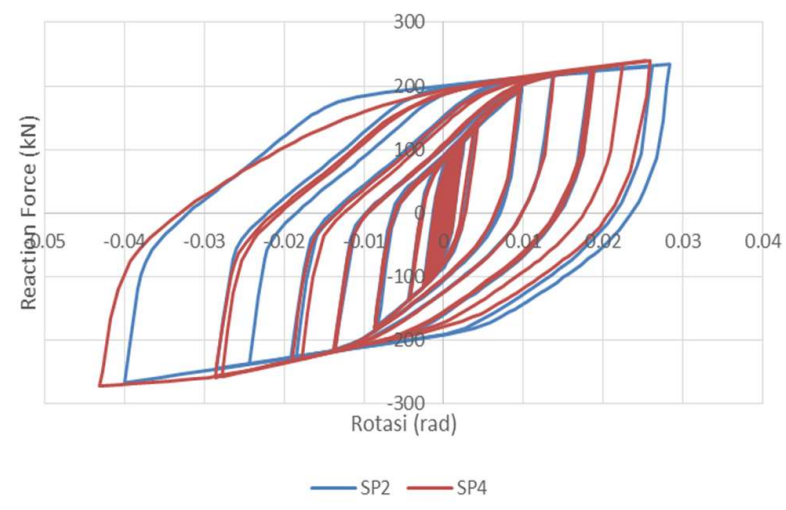

Gambar 57. Perbandingan kurva histerisis spesimen SP2 dan spesimen SP4.

Dari luasan kurva histeresis spesimen, spesimen SP2 sedikit lebih besar dari spesimen SP4 dengan selisih $0,904 \mathrm{Nm}$ atau sebesar 3,83\% yang dapat dilihat pada Tabel 16.

Tabel 16. Perbandingan Energi Disipasi Spesimen SP2 dan Spesimen SP4

\begin{tabular}{ccc}
\hline Spesimen & $\begin{array}{c}\text { Energi Disipasi } \\
(\mathbf{k N m})\end{array}$ & Selisih (\%) \\
\hline SP2 & 23,614 & $3,83 \%$ \\
\hline SP4 & 22,71 & \\
\hline
\end{tabular}

Dari perbandingan kedua spesimen, deformasi yang terjadi saat spesimen mencapai kondisi ultimate spesimen SP2 lebih besar 2,78 mm daripada spesimen SP4 atau sebesar 11,74\% dapat dilihat pada Tabel 17.

Tabel 17. Perbandingan Deformasi Spesimen SP2 dan Spesimen SP4 saat Mencapai Tegangan Maksimum

\begin{tabular}{ccc} 
Spesimen & Deformasi (mm) & Selisih (\%) \\
\hline SP2 & 23,68 & $11,74 \%$ \\
\hline SP4 & 20,9 & \\
\hline
\end{tabular}

Sedangkan perbandingan terkait reaction force terbesar seperti pada Tabel 18, bahwa spesimen SP4 lebih besar 4,48 $\mathrm{kN}$ daripada spesimen SP2 atau sebesar 1,65\%.

Tabel 18. Perbandingan Reaction Force Maksimum Spesimen SP2 dan Spesimen SP4

\begin{tabular}{ccc}
\hline Spesimen & $\begin{array}{c}\text { Reaction Force } \\
\text { Maksimum (kN) }\end{array}$ & Selisih (\%) \\
\hline SP2 & 266,71 & $1,65 \%$ \\
\hline SP4 & 271,19 & \\
\hline
\end{tabular}

\section{Kesimpulan}

Dari hasil analisa Abaqus yang telah dilakukan pada empat jenis spesimen bresing, dapat disimpulkan sebagai berikut:

1. Perbedaan antar spesimen tidak menghasilkan perbedaan signifikan terhadap hasil analisa. Keseluruhan spesimen hampir memiliki bentuk kurva histeresis yang sama meski terdapat perubahan pada bentang dan mutu yang digunakan sebagai pembeda antar spesimen. Pada end hollow dengan mutu yang tinggi memberikan hasil energi disipasi dan reaction force saat ultimate yang tinggi. Sedangkan panjang pendek pada end hollow berpengaruh pada hasil displacement.

2. Hasil analisa reaction force pada masing masing spesimen dipengaruhi oleh tinggi rendahnya mutu yang digunakan. Sedangkan perubahan bentang segmen bresing yang berbeda, memberikan dampak hasil reaction force maksimal yang berbeda. Saat spesimen mencapai reaction force maksimal, rotasi yang terjadi pada spesimen mencapai 0,04 rad. 
3. Pada SP1 yang menggunakan BJ41 pada seluruh element dan SP2 menggunakan BJ37 pada end hollow memberikan dampak pada saat diberikan beban siklik mencapai ultimate yang menghasilkan displacement yang tidak terpaut terlalu besar. Sedangkan SP2 dan SP4 yang mana sama sama menggunakan mutu BJ37 dan bentang yang digunakan berbeda memberikan hasil displacement yang terpaut cukup besar.

4. Energi disipasi yang diperoleh dari luasan kurva histeresis pada setiap spesimen. Pada spesimen SP1 memperoleh energi disipasi $24,14 \mathrm{kNm}$ dan spesimen SP3 diperoleh energi disipasi $24,129 \mathrm{kNm}$. Sedangkan spesimen SP2 memperoleh energi disipasi 23,614kNm dan spesimen SP4 diperoleh energi disipasi 22,71kNm. Hasil dari spesimen SP1 dan spesimen SP3 lebih tinggi daripada spesimen SP2 dan spesimen SP4 karena perbedaan mutu yang digunakan pada spesimen tersebut.

5. Energi disipasi yang diperoleh pada SP1 dan SP2 mendapatkan selisih 2,18\%. Untuk perbandingan energi disipasi pada SP3 dan SP4 adalah 5,88\% dan untuk perbandingan energi disipasi pada SP1 dan SP3 sebesar $0,05 \%$. Serta perbandingan energi disipasi pada SP2 dan SP4 adalah 3,83\%. Energi disipasi pada seluruh spesimen dipengaruhi oleh mutu baja yang digunakan.

6. Dalam hal kemudahan pengaplikasian pelaksanaan, dari keempat spesimen memiliki penampang dan sambungan yang sama sehingga tidak ada perbedaan yang signifikan dalam pengaplikasian pelaksanaan.

\section{DAFTAR PUSTAKA}

[1] C. W. Roeder, E. J. Lumpkin, and D. E. Lehman, “A balanced design procedure for special concentrically braced frame connections," JCSR, vol. 67, no. 11, pp. 1760-1772, 2011, doi: 10.1016/j.jcsr.2011.04.016.

[2] J. Goggins et al., "Shake Table Testing of Concentrically Braced Steel Structures With Realistic Connection Details Subjected to Earthquakes," Structures, vol. 13, no. December 2017, pp. 102-118, 2018, doi: 10.1016/j.istruc.2017.12.003.

[3] N. A. Setiyowati, B. Suswanto, and R. Soewardojo, "Studi Perbandingan Perilaku Profil Baja WF dan HSS Sebagai Bresing pada SCBF Akibat Beban Lateral dengan Program Bantu Finite Element Analysis," vol. 1, no. 1, 2012.

[4] E. J. Lumpkin et al., "Investigation of the seismic response of three-story special concentrically braced frames," J. Constr. Steel Res., vol. 77, pp. 131-144,
2012, doi: 10.1016/j.jcsr.2012.04.003.

[5] Z. Du, Y. Liu, and S. Chan, "A practical analytical model for special concentrically braced frames," $J$. Constr. Steel Res., vol. 155, pp. 219-232, 2019, doi: 10.1016/j.jcsr.2018.12.027.

[6] T. Li et al., "Seismic performance of special concentrically braced frames in deep basins during subduction-zone earthquakes," Eng. Struct., vol. 188, no. February, pp. 87-103, 2019, doi: 10.1016/j.engstruct.2019.02.057.

[7] A. D. Sen, C. W. Roeder, D. E. Lehman, and J. W. Berman, "Nonlinear modeling of concentrically braced frames," J. Constr. Steel Res., vol. 157, pp. 103-120, 2019, doi: 10.1016/j.jcsr.2019.02.007.

[8] K. K. Wijesundara, D. Bolognini, and R. Nascimbene, "Review of Design Parameters of Concentrically Braced Frames with RHS Shape Braces," vol. 13, pp. 109-131, 2009, doi: 10.1080/13632460902813331.

[9] G. Martinez-Saucedo, J. A. Packer, and C. Christopoulos, "Gusset Plate Connections to Circular Hollow Section Braces under Inelastic Cyclic Loading," J. Struct. Eng., vol. 134, no. 7, pp. 1252-1258, 2008, doi: 10.1061/(asce)0733-9445(2008)134:7(1252).

[10] R. Tremblay, M.-H. Archambault, and A. Filiatrault, "Seismic Response of Concentrically Braced Steel Frames Made with Rectangular Hollow Bracing Members," J. Struct. Eng., vol. 129, no. 12, pp. 16261636, 2003, doi: 10.1061/(asce)0733-9445(2003)129: 12(1626).

[11] J. H. Yoo, D. E. Lehman, and C. W. Roeder, "Influence of connection design parameters on the seismic performance of braced frames," J. Constr. Steel Res., vol. 64, no. 6, pp. 607-623, 2008, doi: 10.1016/j.jcsr. 2007.11.005.

[12] O. Seker, B. Akbas, P. T. Seker, M. Faytarouni, J. Shen, and M. Mahamid, "Three-segment steel brace for seismic design of concentrically braced frames," $J$. Constr. Steel Res., vol. 137, no. March, pp. 211-227, 2017, doi: 10.1016/j.jcsr.2017.06.035.

[13] J. Shen, O. Seker, B. Akbas, P. Seker, S. Momenzadeh, and M. Faytarouni, "Seismic performance of concentrically braced frames with and without brace buckling," Eng. Struct., vol. 141, pp. 461-481, 2017, doi: 10.1016/j.engstruct.2017.03.043.

[14] Departemen Pekerjaan Umum, "Tata Cara Perencanaan Struktur Baja untuk Bangunan Gedung," Standar Nas. Indones., 2002. 
Halaman ini sengaja dikosongkan 